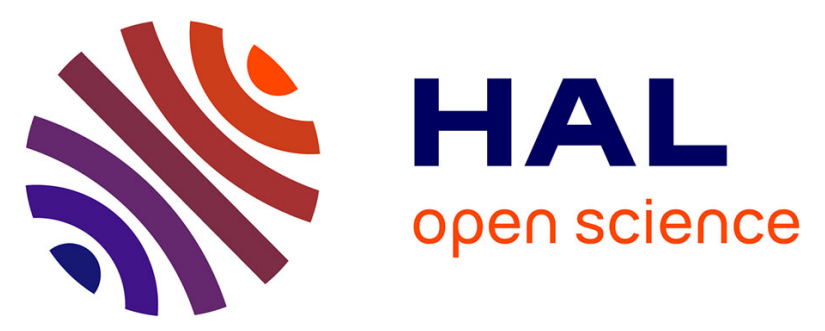

\title{
Blockchain Technology for Enabling Transparent and Traceable Government Collaboration in Public Project Processes of Developing Economies
}

Ebizimoh Abodei, Alex Norta, Irene Azogu, Chibuzor Udokwu, Dirk Draheim

\section{- To cite this version:}

Ebizimoh Abodei, Alex Norta, Irene Azogu, Chibuzor Udokwu, Dirk Draheim. Blockchain Technology for Enabling Transparent and Traceable Government Collaboration in Public Project Processes of Developing Economies. 18th Conference on e-Business, e-Services and e-Society (I3E), Sep 2019, Trondheim, Norway. pp.464-475, 10.1007/978-3-030-29374-1_38 . hal-02510137

\author{
HAL Id: hal-02510137 \\ https://hal.inria.fr/hal-02510137
}

Submitted on 17 Mar 2020

HAL is a multi-disciplinary open access archive for the deposit and dissemination of scientific research documents, whether they are published or not. The documents may come from teaching and research institutions in France or abroad, or from public or private research centers.
L'archive ouverte pluridisciplinaire HAL, est destinée au dépôt et à la diffusion de documents scientifiques de niveau recherche, publiés ou non, émanant des établissements d'enseignement et de recherche français ou étrangers, des laboratoires publics ou privés.

\section{(c)(1)}

Distributed under a Creative Commons Attribution| 4.0 International License 


\title{
Blockchain Technology for Enabling Transparent and Traceable Government Collaboration in Public Project Processes of Developing Economies
}

\author{
Ebizimoh Abodei ${ }^{1}$, Alex Norta ${ }^{10000-0003-0593-8244]}$, Irene Azogu ${ }^{2}$, Chibuzor \\ Udokwu $^{1}$ and Dirk Draheim ${ }^{3}[0000-0003-3376-7489]$ \\ 1 Blockhain Technology Group, Tallinn University of Technology \\ Akadeemia tee 15a, 12618 Tallinn, Estonia \\ alex.norta.phd@ieee.org, ebizimohabodei@gmail.com, cjobuzor@gmail.com \\ 2 Department of Public Policy, University of Regina \\ 2155 College Ave, Regina, SK S4P 4V5, Canada \\ ina679@uregina.ca \\ 3 Information Systems Group, Tallinn University of Technology, \\ Akadeemia tee 15a, 12618 Tallinn, Estonia \\ dirk.draheim@taltech.ee
}

\begin{abstract}
Infrastructural development is a significant determinant of economic growth. It remains an elusive pursuit for many developing economies suffering from public infrastructural project failures. Although the causes of these failures are identifiable, they remain persistent. Government corruption has been identified as the primary cause of project failures amidst a host of other causal factors, spurred by the ambiguity in public service administration. These factors heighten capital expenditures and hence, the need for more transparent systems in public infrastructural project planning and -delivery. This research uses a case-study methodology to examine the importance of public involvement in addressing the causes of failures in public infrastructural project planning and -delivery. Using Nigeria as a case, the findings from conducted interviews and a documents review support the proposition of a technologically collaborative approach in addressing the causes of public infrastructural project failures. The institutionalization of transparency-enhancing blockchain systems are vital in government and public involvement in the processes of public infrastructural project planning and -delivery.
\end{abstract}

Keywords: Collaborative public governance, public infrastructural development, policy, administration, blockchain technology, smart contracts.

\section{Introduction}

Many public infrastructure projects in developing countries suffer failures that result in declining economic growth and societal underdevelopment. Projects that measure a country's growth and economic standard are identified as the 
building blocks of development. From previous research, it is evident that factors impeding the success of public infrastructural projects are common in developing nations. Identified as recurring factors, some of them include corruption, non-transparency, unaccountability, and budget overruns, inadequate monitoring, change in government and political interferences, and poor communication between different stakeholders [14, 22, 42]. Although these causal factors are identifiable, they have still not been addressed, and thus, developing countries are in a perpetual state of economic regress, or stagnation. Additionally, these infrastructural development projects are very costly and considered a loss for citizens with high expectations for public service delivery.

Over the last decade, Nigeria has budgeted an average of $28 \%$ on capital expenditure projects to improve public infrastructure development for better living conditions. Still, the government has not been able to deliver its promises to citizens due to many inconsistencies in the delivery system. For instance, even after over 40 years of independence, Nigeria only has $15 \%$ paved roads ${ }^{4}$. As a result, there has been a drastic reduction of public trust in government, stakeholders have also been discouraged from investing in the nation's economy, which leaves a negative mark on governance. Thus, the question remains, how can developing countries such as Nigeria overcome these challenges?

The complexities and challenges with managing the process of project delivery has attracted various technological solutions. One of such attraction is blockchain technology [40], a disruptive innovation with a wide range of applications to provide better management systems in many sectors by constituting trust, transparency, and traceability. The dynamic grouping of different actors/companies with cross-dependencies requires a decentralized system where trust is decisive. Blockchain technologies for decentralized networks and its different use-cases, present novel solutions leading to the creation of a digital society where information- and communication technologies are geared towards the provision of solutions to societal problems.

This paper explores the factors that plague public project processes in developing nations, while using Nigeria as a case study. Thus, Section 2 presents related work and Section 3 details the chosen research methodology. Next, Section 4 presents the case selection, subject description and result presentation. Section 5 discusses the research findings. In, Section 6 we discusses limitations and future work. We finish the paper with a conclusion in Section 7.

\section{Related Work}

The term collaboration is a focus in public governance and also in diverse fields including environmental management, conflict resolution, private sector, education, and research. The wide application of this yields several definitions based on the purpose served. In connection to public governance, collaboration stems from the public participation and is a new paradigm of democratic governance in

\footnotetext{
${ }^{4}$ https://tradingeconomics.com/nigeria/roads-paved-percent-of-total-roads-wbdata.html
} 
the field of public administration[18] in reaction to previous government failures [3]. Collaboration is also a model for problem solving in this digital- and postindustrial age [6]. Collaboration as a need in society is not addressed adequately by the elected officials [12]. Furthermore, the bureaucracy, complexities and multifaceted challenges of contemporary governance are more visible [19]. Though the earliest forms of public participation comprise the representation of political party members [35], government is seeking now more active and deliberative ways of public engagement in diverse spheres.

Much of the scientific literature in collaborative public governance focuses on single-case studies concentrating on sector-specific collaborative management for solving individual problems within the public sector. The first public collaborative networks are centered on delivering public inclusion in federal agencies' decision-making processes in response to increasing public frustration on futile efforts in maintaining the government's status quo [35]. The growing importance of public participation attracts research for the involvement of citizens in planning and decision-making processes, relaying the assurance of more widely accepted programs, policies and projects [17].

Collaborative public governance presents several valuable theories compared to traditional forms of governance. One of such arguments is collaborative advantage argued by scholars as a decisive factor towards widely accepted public policies and decisions $[10,15,25]$, stating that problems in public governance are very complex to resolve only by public officials. Additionally, $[7,8]$ introduce the theory of collective intelligence and crowd wisdom with the idea that collaborative public governance networks harness the collective intellect embedded in public circles. Individuals are imperfect and often let emotions cloud their judgments [37]. Nevertheless, despite these limitations, when all imperfect judgments are accumulated and aggregated rightly, collective intelligence is often excellent. Extending these notions further, citation [7] also introduces the concept of nonexpert knowledge as a benefit to public participatory networks by explaining the inclusion of citizens accompanies non-expert, or non-mainstream knowledge in the creative problem-solving process.

Theories in collaborative public governance are also related to public participation theories, relaying the values and benefits of engaging and involving citizens in the public decision-making process [26]. Public participation improves public policy decision quality, minimizes cost and delays [13]. In study [13] the authors observe that unilateral decisions by public officials suffer delays in implementation due to resistance, controversy, and litigation, while in some cases, these decisions are never implemented. Resolutions with public participation sustain delays in reaching a consensus; conversely, implementation runs smoothly and quickly. Furthermore, unilateral decisions are highly consequential in the long run as policies and projects are frustrated by citizens. Although time and cost do not only measure efficiency, decisions with public participation remain sustained by future users with expressions of trust for government.

While most studies view collaborative public governance positively, some literature emphasizes the difficulties in managing the complexity of the process 
[32], e.g., there is the problem of ethnic rivalry. The study [5] argues that how a particular ethnic group presents a project idea may divide between the minorities and the mainstream. Research in [9] warns that there is a lack of empirical evidence that reveals the successes of public participation and points to the fact that negotiating can culminate into high levels of argument, slows down projects and frustrates project managers. Citation [1] sees collaborative public governance as consensus-seeking, where a consensus is usually not reached, and the government still reserves the authority to make the final decision.

Although some project managers argue that public consultation in project execution is professionally hazardous, the importance of civic engagement is still paramount. First, there is the case of stronger plans and increased chances of proper implementation when there is public inclusion. In [23], it is argued that public participation ensures that local knowledge is embedded in project plans and culminate better ideas as a result of continuous exchange of information between the public and project managers. Governance refers to the rules and forms that guide collective decision-making where the focus is on decisionmaking. Thus, governance focuses on groups of individuals, organizations, or systems of an organization making decisions [36].

\section{Research Methodology}

Initially, we present a problem statement of public infrastructural project delivery in developing economies. Then, a potential solution is suggested as collaborative public management. Although backed by peer-reviewed literature and theories, this proposition still has to be tested and validated. Thus, part of the research covers the testing of that proposition commencing by selecting the case and providing the research questions for the study. We conduct case study-based research [33] for data collection and analysis. For the remainder, Section 3.1 describes the case study design and Section 3.2 explains the sample selection for semi-structured interviews.

\subsection{Case-Study Design}

The selection of our case is based on the consideration of cross-case characteristics with developing economies to allow for a generalization of theoretical propositions [20]. The research is qualitative and includes both primary- and secondary data collection methods to ensure the validity of the study triangulation [41]. Documents are reviewed, and semi-structured interview questions have bee developed to collect primary data. For data analysis, we employ a tool-based thematic analysis using the open-source R software package RQDA (R Qualitative Data Analysis) [16]. We follow the six (6) phase data analysis guide [27] for using RQDA. 


\subsection{Survey-Sample Selection}

The sample size for data collection is ten respondents, from different regions of the case. The selection of respondents is based on their knowledge and experience in the research domain. Three (3) experts stem from the private sector, five (5) are public service officials and two (2) are members of the public.

The survey starts by exploring existing public participatory methods, evaluating their relevance and effectiveness. Our research extends to identifying and understanding the challenges and causes of public infrastructural project failure. This is essential, because exploring how government collaboration can improve public infrastructural project success, first requires identifying the common problems and causes of failures. The research questions also examine how government collaboration improves the success rate of public infrastructure projects and increases economic growth in the long run. We investigate this by measuring the efficiency, benefits, and suitability of the network in addressing the identified challenges tied to public infrastructure project delivery.

\section{Case Selection, Subject Description and Results}

In Section 4.1, we present the detailed description of the case and subjects. Next, Section 4.2 presents the results of this research. Finally, in Section 4.3, we map blockchain technology into solving problems that currently exist in public-private partnership (PPP) projects.

\subsection{Case and Subject Description}

The selected case for this study is Nigeria - a typical example of a developing country with a high population and considerably large economy. The case selection allows to extend our research findings to a broad range of developing economies. Nigeria is commonly compared with developing economies including Saudi Arabia, Brazil, Ghana, Malaysia, India, Ghana, Nepal, and Bangladesh. The case reflects a wide range of developing economies and suffers numerous public infrastructural failures over the years.

Many researchers argue that Nigeria's poor state of infrastructural development is due to the military rule for many years. The advent of democracy in 1999 has only seen the rise in corruption and alienation of the populace due to allegations that massive rigging has marred the various elections held in the country. The leadership does not truly reflect the votes of the people and this is also manifested in the poor state of infrastructural development that results in a decline of the economy. These events stem from gross failures by the government in project delivery, aided by little, or no public participation in the decisionmaking process. To provide a vivid meaning of project failure, the project lead advisor of the United Nations Industrial Development Organization adequately explains: "In project management, a project fails not only when the project delivery refuses to meet the use or the needs of the project, or when the project's 
product refuses to satisfy the end-user, but when the project is not accomplished within the allowed time frame, project budget, scope defined for the project and even when the outcome of the project is rejected by the stakeholder."

In Nigeria, about $60-80 \%$ of projects fail. According to Vanguard Newspaper in the country, dated 24 th Aug $2015^{5}$, project managers have claimed that the nation achieves only a $39 \%$ success on projects.

\subsection{Result Presentation}

This section presents the findings from our semi-structured interviews. With thematic analysis we found the following specific topic themes:

- level of economic development,

- rate of project delivery/success,

- importance of public involvement,

- current participatory approach,

- collaboration as a potential solution,

- measuring efficiency and effectiveness,

- challenges with using the Web/Internet.

Level of Economic Development The state of economic development in Nigeria is deplorable. Results endorse the fact that Nigeria is in a perpetual state of economic stagnation and a significantly low pace of economic growth. Responses are disparate due to regional economic inequality. The results also show that the causes of the slow-, or low economic growth are chiefly due to corrupt practices by the government, tribalism, a high rate of public infrastructural failures, and poor communication between the government and public.

Rate of Project Delivery/Success The success rate of public infrastructural projects as described by respondents is below average. The causes of failures include organizational bureaucracy and complexities, government instability, market fluctuations, poor implementation and monitoring processes, tribalism and public exclusion from the process of planning and delivery.

Importance of Public Involvement Respondents consider public participation to play a significant role in infrastructural project delivery. Although elusive and not widely practiced in Nigeria, we identify key criteria to allow for the implementation of a stable participatory process. Respondents mention that public policies and decisions are accepted where the government only implements relevant policies. Citizens take it as a duty to checkmate government activities due to the transparent system with an increased public contribution to project success. Assuring project success is shared and citizens take ownership of public programs. Accruing more importance, the quality of decisions increases due to the sampling of a wider pool of knowledge.

\footnotetext{
${ }^{5}$ https://www.vanguardngr.com/2015/08/60-of-projects-fail-in-nigeria-unido/
} 
Current Participatory Approach Public participation methods are notable in infrastructural project planning and delivery. The common approach is in town hall meetings and public opinion hearings. The expectations of citizens with the current techniques are unactualized, contributing to the reduced public interest in the process with lacking trust and confidence in governance. Thus, participation is merely a constitutional theory. Current methods are deemed unproductive for several reasons including the size of the population, power dynamics, and non-transparency.

Collaboration as a Potential Solution Inferences suggest that public participation in the process of infrastructural project planning and delivery accompany a positive impact. As a more comprehensive solution alongside the implementation, government officials mention the following as secondary additions: a collaborative network, punitive measures, stronger monitoring institutions and stringent legal actions against corrupt practices by. Emphasizing the need for collaboration and an open system, one respondent opined: "Transparency is the bedrock of any system that will address the current challenges in project delivery."

Measuring Efficiency and Effectiveness One commonality from inferences is that the impact of the proposed collaborative network is evident, fostered by transparent systems that curb corrupt practices, e.g., blockchain technology. The assessment of impact can only be performed after the implementation, and there is currently no specific metric for evaluating productivity.

Challenges in Using the Web/Internet The internet remains a luxury in Nigeria, and most citizens have little or no accessibility to web services. Information technology (IT) literacy, the cost, and level of internet coverage are specified as the most common challenge with using the Web/Internet as a participatory approach. Nonetheless, there is a widespread view that the government has the resources to address these challenges.

\subsection{Mapping Blockchain Technologies to PPP Problems}

We propose a blockchain-based technical solution in Table 1 to address the problems identified in 4.2. A blockchain-based collaborative tool for managing public project execution addresses issues including project complexity, corruption, inadequate project monitoring by providing a system that enables trust and transparency. We also provide the references of blockchain technologies and smartcontract based projects that provide solutions similar to the proposals provided in the table. 
Table 1. Mapping PPP problems onto blockchain technology solutions

\begin{tabular}{|c|c|c|c|}
\hline $\begin{array}{l}\text { Problem } \\
\text { Theme }\end{array}$ & Findings & $\begin{array}{l}\text { Blockchain } \\
\text { Technology }\end{array}$ & Application and Impact \\
\hline $\begin{array}{l}\text { Level of economic } \\
\text { development. }\end{array}$ & $\begin{array}{l}\text { Inadequate } \\
\text { communication } \\
\text { between the } \\
\text { government and } \\
\text { public. }\end{array}$ & $\begin{array}{l}\text { Digital } \\
\text { Signature, } \\
\text { Consensus. }\end{array}$ & $\begin{array}{l}\text { e-Participation tool based on } \\
\text { blockchain enables the } \\
\text { identification of citizens using } \\
\text { unique digital signatures. } \\
\text { Agreement reached through such } \\
\text { platform cannot be manipulated } \\
\text { by any party [21]. }\end{array}$ \\
\hline $\begin{array}{l}\text { Rate of project } \\
\text { delivery/success. }\end{array}$ & $\begin{array}{l}\text { High rate of } \\
\text { project failure } \\
\text { caused by } \\
\text { corruption, } \\
\text { bureaucracy and } \\
\text { project } \\
\text { complexity. }\end{array}$ & $\begin{array}{l}\text { Smart Contract, } \\
\text { Cryptocurrency, } \\
\text { Consensus. }\end{array}$ & $\begin{array}{l}\text { Smart contracts enable } \\
\text { transparency in terms of project } \\
\text { execution. Payments for project } \\
\text { execution is performed when } \\
\text { certain conditions in the smart } \\
\text { contract (project conditions) are } \\
\text { met }[11,34] \text {. }\end{array}$ \\
\hline $\begin{array}{l}\text { Importance of } \\
\text { public } \\
\text { involvement. }\end{array}$ & $\begin{array}{l}\text { Benefits derived } \\
\text { in knowledge } \\
\text { sharing. } \\
\text { Transparency } \\
\text { renders } \\
\text { government more } \\
\text { accountable. }\end{array}$ & $\begin{array}{l}\text { Consensus, } \\
\text { Smart Contract. }\end{array}$ & $\begin{array}{l}\text { Consensus allows participants to } \\
\text { contribute based on defined } \\
\text { messages. Smart contract enables } \\
\text { traceability and accountability } \\
\text { since every activity is visible on } \\
\text { blockchains [4]. }\end{array}$ \\
\hline $\begin{array}{l}\text { Current } \\
\text { participatory } \\
\text { approach. }\end{array}$ & $\begin{array}{l}\text { Current methods } \\
\text { are ineffective, do } \\
\text { not influence } \\
\text { project outcomes } \\
\text { or decisions. }\end{array}$ & $\begin{array}{l}\text { Digital } \\
\text { Signature, Smart } \\
\text { Contract }\end{array}$ & $\begin{array}{l}\text { A blockchain-based collaborative } \\
\text { platform provides the possibility } \\
\text { for people to express their ideas on } \\
\text { specific government projects [39]. }\end{array}$ \\
\hline $\begin{array}{l}\text { Collaboration as } \\
\text { a potential } \\
\text { approach. }\end{array}$ & $\begin{array}{l}\text { Collaboration is } \\
\text { not a complete } \\
\text { solution. }\end{array}$ & NA & NA \\
\hline $\begin{array}{l}\text { Measuring } \\
\text { efficiencies and } \\
\text { effectiveness. }\end{array}$ & $\begin{array}{l}\text { No metric for } \\
\text { measurement of } \\
\text { project success. }\end{array}$ & Smart Contract & $\begin{array}{l}\text { Smart contract shows project } \\
\text { milestones, providing the status of } \\
\text { projects for tracking and } \\
\text { monitoring, even after completion } \\
{[38]}\end{array}$ \\
\hline $\begin{array}{l}\text { Challenges with } \\
\text { using the } \\
\text { Web/Internet. }\end{array}$ & $\begin{array}{l}\text { Low rate of } \\
\text { internet users. }\end{array}$ & NA & $\mathrm{NA}$ \\
\hline
\end{tabular}




\section{Discussions}

While we refer the reader to [2] for the extended version of this research, investigating the causes of infrastructure project failures reveals various factors that are disjointed. Studying the factors holistically, it is apparent that a transparent system in project delivery fosters better management and accountability. Furthermore, an essential finding in this paper is that a one-for-all solution does not adequately address all the problems. It is vital to engage the public in the planning and delivery processes of infrastructure projects.

With the above as a background, we start by suggesting a consensus-driven collaborative network based on blockchain-based technology. This approach is particularly useful for security, authentication and transparency reasons [24], to prevent the participatory process from being hijacked by stakeholders with adverse interest/intent. The collaborative network is also purposed to gain novel insight from the public, engaging them to identify the most critical needs and, eventually, gain trust, commitment, and share the responsibility of project delivery. The application of blockchain technology in governance is not a new idea $[30,31]$, with the use of digital signatures, e.g., with the Estonian state as an example. Thus, citizens securely communicate with their representatives, reach a consensus on project messages and track the process of implementation in the network - instituting transparency and accountability.

In [40], the authors discuss, the potentials of a blockchain-based contract and procurement-management systems in delivering a seamless and transparent stream of project activities. Blockchain technology enables interaction between the government and citizens and [40] provides potential components to address corruption further, producing a complete solution to redress project failures. In Nigeria for instance, the contract bidding and procurement processes have been negated by nepotism and corruption. These have resulted in delays in infrastructure project deliveries.

These additional blockchain components prove valuable in identifying gridlocks during the planning and implementation process. To extend this thought, smart contracts manage project contracts and release payments according to rules-based operations. The cross verification of the process by all participants prevents exploitation and strengthens confidence in a blockchain-technology system [28]. Smart contracts are especially useful in the procurement of service and materials, supply-chain management, providing integrity in the bidding process by reducing redundancy, marginal cost, corruption and conflict of interests due to transparency [29]. Additionally, payments can be initiated automatically using cryptocurrency to contractual parties when the prescribed requirements are met to prevent insolvency and late payments.

In summary, governance transparency plays a vital role in ensuring trust and accountability. To this effect, blockchain technology offers tangible gains such as confidentiality, disintermediation, provenance tracking, non-repudiation, multiparty aggregation, change tracing, traceability, and recordkeeping. Instrumentally, blockchain technology establishes transparent systems in infrastructure 
project delivery and renders it easier for a broad set of stakeholders, including the public, to monitor the whole process from start to finish.

\section{$6 \quad$ Limitions and Future Directions}

It is undeniable that the approach presented in this paper is accompanied by some challenges due to the specific digital divide in developing countries. Thus, to ensure the inclusiveness of some groups of citizens that are unable to participate, other methods of participation should be considered such as the broad use of mobile devices that are widely adopted in developing countries. Finally, it is vital to implement a robust legislative and regulative framework to serve as a background and guide for the collaborative network, in order to preserve government commitment in the participatory process.

One limitation of this research can be drawn directly from the criticisms of single case study-based research. Secondly, the paper proposes a solution to problems but fails to investigate the feasibility of its implementation. Another significant limitation of this study is the issue of external validity, or generalisability. In future work, a related field of study is the development of a blockchain-based collaborative framework for public infrastructural project planning and -delivery.

\section{Conclusion}

The barriers to successful infrastructure project delivery are plenteous and encapsulated in government corruption. The multifacetedness of corruption undermines the success of most proposed solutions and hence, failures in project delivery remain persistent. Further studying the underlying factors driving corruption, we identify government non-transparency and lack of communication with the public as the main causes of project failures in the long run. As a strategy to institute communication between the government and citizens, and transparent systems, a consensus-driven collaborative network based on blockchain is recommended. To address the failure factors directly and also provide a comprehensive solution, other blockchain-based technologies such as smart contracts, digital signatures, diverse consensus algorithms, and crypto-currencies are suggested as additional components of such a collaborative network.

\section{References}

1. Simone Abram and Richard Cowell. Learning policy - the contextual curtain and conceptual barriers. European Planning Studies, 12(2):209-228, 2004.

2. Ebizimoh Adobei. Enabling government public collaboration in public project processes in developing economies - A case study of Nigeria, Master Thesis, Tallinn University of Technology, 2018. https://digi.lib.ttu.ee/i/file.php?DLID=10947t=1.

3. Chris Ansell and Alison Gash. Collaborative governance in theory and practice. Journal of public administration research and theory, 18(4):543-571, 2008.

4. Arati Baliga. Understanding blockchain consensus models. In Persistent. 2017. 
5. Yasminah Beebeejaun. The participation trap: The limitations of participation for ethnic and racial groups. International Planning Studies, 11(1):3-18, 2006.

6. Daren C Brabham. Crowdsourcing as a model for problem solving: An introduction and cases. Convergence, 14(1):75-90, 2008.

7. Daren $\mathrm{C}$ Brabham. Crowdsourcing the public participation process for planning projects. Planning Theory, 8(3):242-262, 2009.

8. Daren C Brabham. Using crowdsourcing in government, Collaborating Across Boundaries Series, Washington DC: IBM Center for the Business of Government, 2013.

9. Samuel D Brody. Measuring the effects of stakeholder participation on the quality of local plans based on the principles of collaborative ecosystem management. Journal of planning education and research, 22(4):407-419, 2003.

10. John M Bryson, Fran Ackermann, and Colin Eden. Discovering collaborative advantage: The contributions of goal categories and visual strategy mapping. Public Administration Review, 76(6):912-925, 2016.

11. Vitalik Buterin et al. A next-generation smart contract and decentralized application platform. white paper, 2014.

12. Terry L Cooper, Thomas A Bryer, and Jack W Meek. Citizen-centered collaborative public management. Public Administration Review, 66:76-88, 2006.

13. James L Creighton. The public participation handbook: Making better decisions through citizen involvement. John Wiley \& Sons, 2005.

14. IS Damoah, C Akwei, and Y Mouzughi. Causes of government project failure in developing countries - focus on ghana. In Conference Proceedings of the 2015 British Academy of Management Conference, 2015.

15. Carey Doberstein. Designing collaborative governance decision-making in search of a collaborative advantage. Public Management Review, 18(6):819-841, 2016.

16. Samantha Estrada. Qualitative analysis using R: A free analytic tool. The Qualitative Report, 22(4):956-968, 2017.

17. Roger Fisher, William L Ury, and Bruce Patton. Getting to yes: Negotiating agreement without giving in. Penguin, 2011.

18. H. George Frederickson. Toward a theory of the public for public administration. Administration \& Society, 22(4):395-417, 1991.

19. Archon Fung. Varieties of participation in complex governance. Public administration review, 66:66-75, 2006.

20. John Gerring. Case study research: Principles and practices. Cambridge University Press, 2006.

21. Rifa Hanifatunnisa and Budi Rahardjo. Blockchain based e-voting recording system design. In Proceedings of TSSA 2017 - the 11th Intl. Conf. on Telecommunication Systems Services and Applications, pages 1-6. IEEE, 2017.

22. Dubem I. Ikediashi, Stephen O. Ogunlana, and Abdulaziz Alotaibi. Analysis of project failure factors for infrastructure projects in Saudi Arabia: A multivariate approach. Journal of Construction in Developing Countries, 19(1):35, 2014.

23. Judith E Innes. Information in communicative planning. Journal of the American Planning Association, 64(1):52-63, 1998.

24. Ori Jacobovitz. Blockchain for identity management. The Lynne and William Frankel Center for Computer Science Department of Computer Science. BenGurion University, Beer Sheva, 2016.

25. Erik W Johnston, Darrin Hicks, Ning Nan, and Jennifer C Auer. Managing the inclusion process in collaborative governance. Journal of Public Administration Research and Theory, 21(4):699-721, 2010. 
26. Cheryl Simrell King, Kathryn M Feltey, and Bridget O'Neill Susel. The question of participation: Toward authentic public participation in public administration. Public administration review, 58(4):317-326, 1998.

27. Moira Maguire and Brid Delahunt. Doing a thematic analysis: A practical, stepby-step guide for learning and teaching scholars. AISHE-J: The All Ireland Journal of Teaching and Learning in Higher Education, 9(3), 2017.

28. Jim Mason. Intelligent contracts and the construction industry. Journal of Legal Affairs and Dispute Resolution in Engineering and Construction, 9(3), 2017.

29. Malachy Mathews, Dan Robles, and Brian Bowe. BIM+ blockchain: A solution to the trust problem in collaboration? Dublin Institute of Technology, 2017.

30. Julie Maupin. The G20 countries should engage with blockchain technologies to build an inclusive, transparent, and accountable digital economy for all. Technical report, Economics Discussion Papers, 2017.

31. Amy Nordrum. Govern by blockchain - Dubai wants one platform to rule them all, while Illinois will try anything. IEEE Spectrum, 54(10):54-55, 2017.

32. Clare Rigg and Noreen O'Mahony. Frustrations in collaborative working: Insights from institutional theory. Public Management Review, 15(1):83-108, 2013.

33. P. Runeson, M. Höst, A. Rainer, and B. Regnell. Case study research in software engineering - Guidelines and examples. Wiley Online Library, 2012.

34. Jagdeep Sidhu. Syscoin: A peer-to-peer electronic cash system with blockchainbased services for e-business. In Proceeding of ICCCN'2017 - the 26th Intl. Conf. on Computer Communication and Networks, pages 1-6. IEEE, 2017.

35. Nancy Perkins Spyke. Public participation in environmental decisionmaking at the new millenium: Structuring new spheres of public influence. BC Envtl. Aff. L. Rev., 26:263, 1998.

36. Gerry Stoker. Public value management: a new narrative for networked governance? The American review of public administration, 36(1):41-57, 2006.

37. James Surowiecki. The wisdom of crowds. Anchor, 2005.

38. Žiga Turk and Robert Klinc. Potentials of blockchain technology for construction management. Procedia engineering, 196:638-645, 2017.

39. Christoph Van der Elst and Anne Lafarre. Bringing the AGM to the 21st century: Blockchain and smart contracting tech for shareholder involvement. ecgi Law Series, 258, 2017.

40. Jun Wang, Peng Wu, Xiangyu Wang, and Wenchi Shou. The outlook of blockchain technology for construction engineering management. Frontiers of engineering management, 4(1):67-75, 2017.

41. Robert K Yin. Case study research and applications: Design and methods. Sage publications, 2017.

42. Tarila Zuofa et al. Project failure: The way forward and panacea for development. International Journal of Business and Management, 9(11), 2014. 